$$
\begin{aligned}
& \text { STATE OF FLORIDA } \\
& \text { STATE BOARD OF CONSERVATION } \\
& \text { DIVISION OF GEOLOGY }
\end{aligned}
$$

FLORIDA GEOLOGICAL SURVEY

Robert O. Vernon, Director

\author{
INFORMATION CIRCULAR NO. 42
}

\title{
SUMMARY OF FLORIDA PETROLEUM PRODUCTION AND EXPLORATION IN 1962
}

By

Clarence Babcock

TALLAHASSEE 



\author{
STATE OF FLORIDA \\ STATE BOARD OF CONSERVATION \\ DIVISION OF GEOLOGY \\ FLORIDA GEOLOGICAL SURVEY \\ Robert O. Vernon, Director
}

INFORMATION CIRCULAR NO. 42

\title{
SUMMARY OF FLORIDA PETROLEUM \\ PRODUCTION AND EXPLORATION \\ IN 1962
}

By

Clarence Babcock

TALLAHASSEE

1964 


\section{Completed manuscript received}

April 8, 1963

Printed by the Florida Geological Survey

Tallahasseo 


\section{TABLE OF CONTENTS}

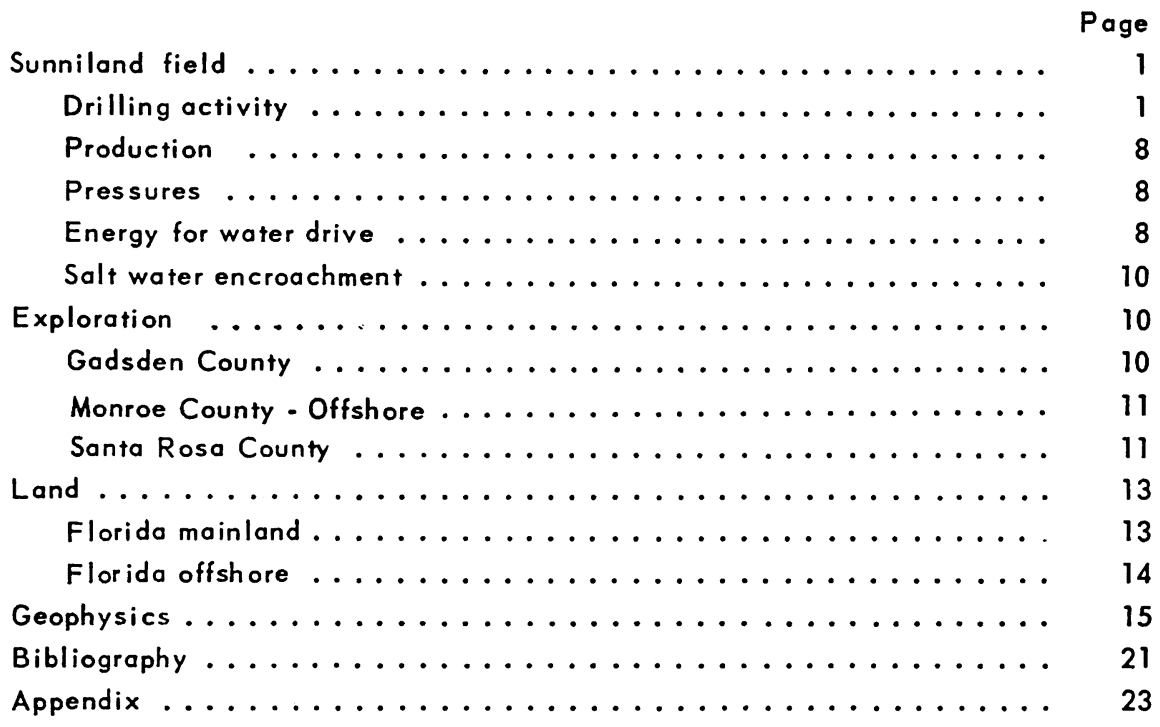

\section{ILLUSTRATIONS}

Figure

1 Florida petroleum exploration and production, $1962 \ldots \ldots \ldots 2$

2 Location map of Sunniland field .................. 3

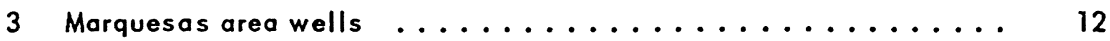

4 Offshore Florida state leases, December $31,1962 \ldots \ldots \ldots 16$

\section{Table}

1 Sunniland field production and structural statistics . . . . . . . . . 4

2 Structural and thickness comparisons of the producing intervals in

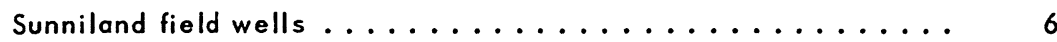

3 Sunniland field pressures and fluid levels.............. 9

4 Geophysical activity in Florida in $1962 \ldots \ldots \ldots \ldots \ldots$

5 Crew weeks of geophysical activity in Florida, 1941-61, inclusive. 18 



\section{SUMMARY OF FLORIDA PETROLEUM PRODUCTION AND EXPLORATION \\ IN 1962}

By

Clarence Babcock

\section{SUNNILAND FIELD}

\section{DRILLING ACTIVITY}

Activity in 1962 in the Sunniland field, operated by the Humble Oil and Refining Company, and located in Collier County, Florida, as shown in figure 1, has been greater than for any year since 1949. Two new wells have been drilled and completed as producers; also, a permit has been issued for the deepening of an old well. These tests, together with other wells in the immediate area of the Sunniland field, are shown on figure 2 , a location map.

Production in the Sunniland field is from a fossiliferous carbonate section occurring in the upper part of the middle member of the Sunniland formation of Lower Cretaceous Trinity Age, as defined in Raasch's type section (1954, p. 8). Production and structural statistics on field wells which have produced commercial quantities of oil from this section, including the two wells drilled in 1962, are presented in table 1, which reveals the following facts: (1) Most of the 16 Sunniland field wells have been good producers, with one well producing about $11 / 3$ million barrels of oil, while two other wells have produced almost a million barrels each; (2) the last two columns of this table show that generally less water is produced from wells that are structurally high than from wells that are structurally low; also, the percentage of salt water production by individual wells has increased markedly; (3) since all of the wells produce large percentages of salt water at the present time, it is inferred that most of the production is from a gradational zone rather than from above a sharp oil-water contact. 


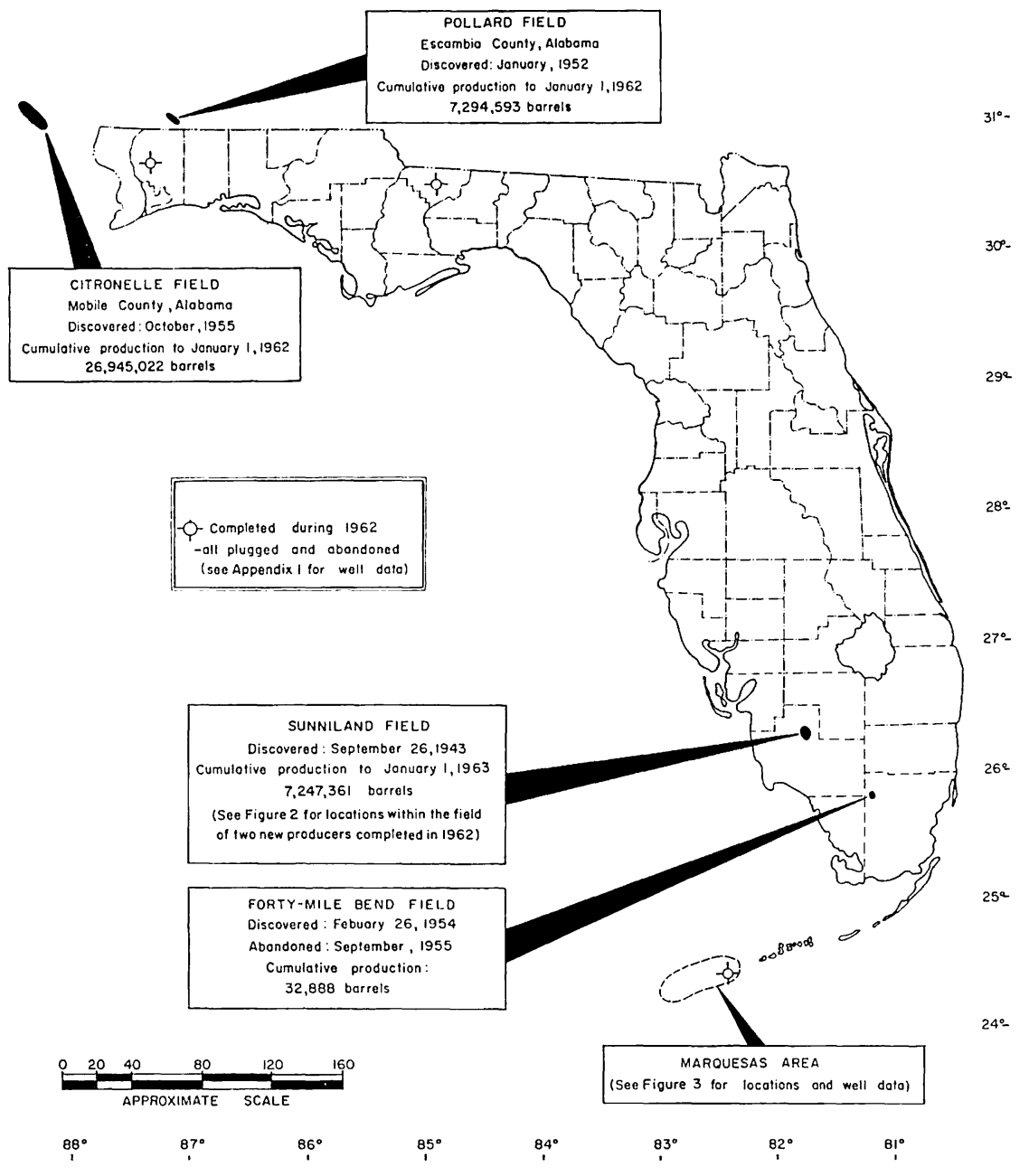

Figure 1. Florida petroleum exploration and production, 1962. 


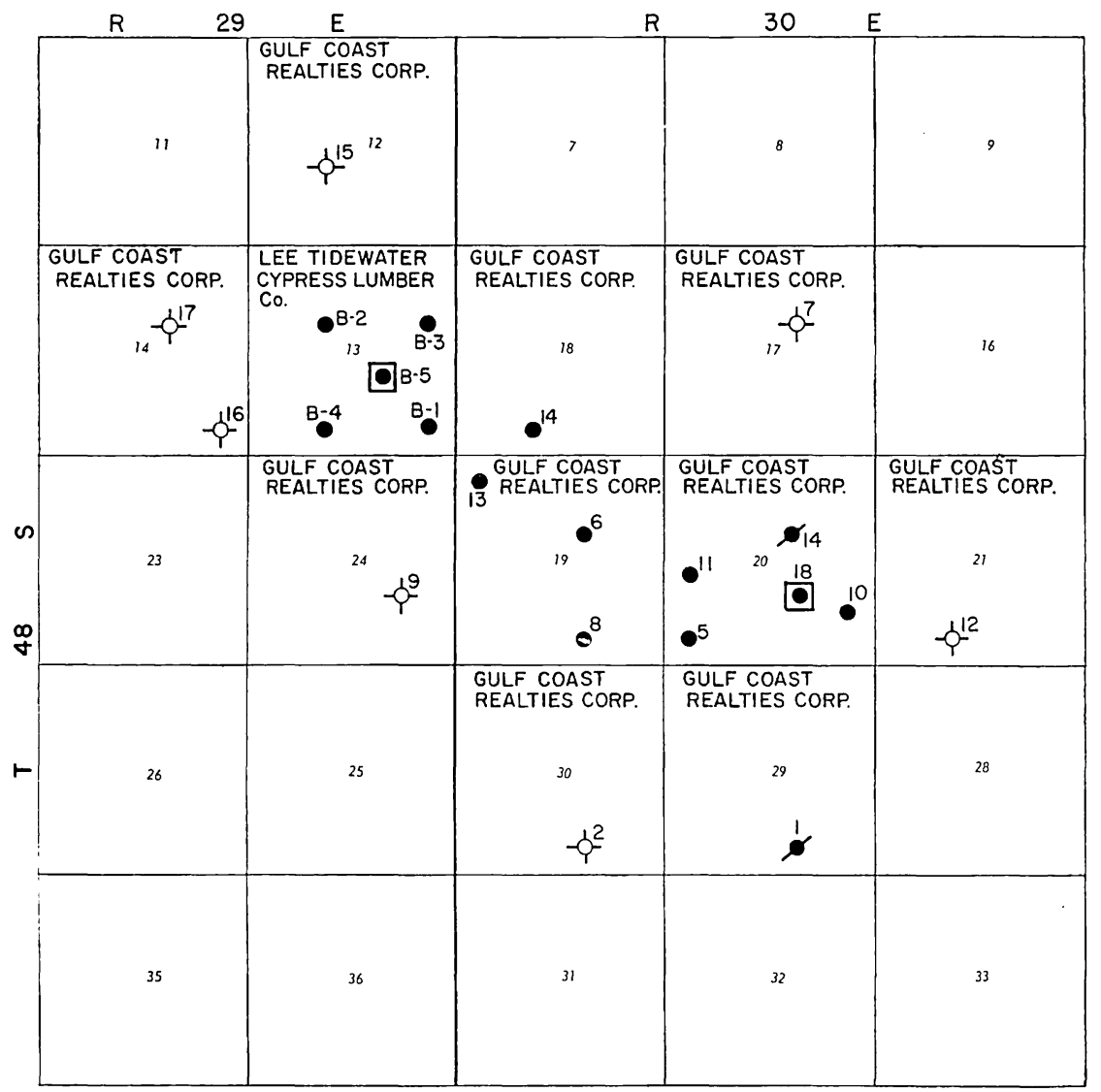

- PRODUCING WELL

(COMPLETED, W6L2)

ABANDONED WELL

- - DRY HOLE

Figure 2. Location map of Sunniland field. 
Table 1. Sunniland Field Production and Structural Statistics

\begin{tabular}{|c|c|c|c|c|c|c|c|c|c|c|}
\hline \multirow{2}{*}{\multicolumn{2}{|c|}{ Farm and no. }} & \multicolumn{3}{|c|}{ Initial production } & \multicolumn{2}{|c|}{$\begin{array}{l}\text { Production test } \\
\text { Sept. } 1962 \\
\end{array}$} & \multicolumn{3}{|c|}{$\begin{array}{l}\text { Accumulated production } \\
\text { (to Oct. } 1,1962)^{1}\end{array}$} & \multirow{2}{*}{$\begin{array}{c}\text { Top of } \\
\begin{array}{c}\text { Sunniland marker } \\
\text { (feet) }\end{array}\end{array}$} \\
\hline & & \multicolumn{2}{|l|}{ BOPD } & $\begin{array}{c}\text { Percent } \\
\text { BS and } W\end{array}$ & BOPD & $\begin{array}{c}\text { Percent } \\
\text { Salt water }\end{array}$ & Bbls. oil & $\begin{array}{c}\text { Bbls. } \\
\text { salt water }\end{array}$ & $\begin{array}{c}\text { Percent } \\
\text { salt water }\end{array}$ & \\
\hline $\begin{array}{l}\text { Gulf Coast Rea } \\
\text { Corporation w } \\
\text { (arranged in o } \\
\text { of structural e }\end{array}$ & $\begin{array}{l}\text { lities } \\
\text { ells } \\
\text { rder } \\
\text { lev.) }\end{array}$ & & & $\cdot$ & & & & & & \\
\hline No. & 18 & Pump & 178.7 & 11.1 & & (Complete & ct. 18, 1962) & & & $11,527(-11,493)$ \\
\hline & 11 & Flow & 120 & 1.0 & Pump I 80 & 7 & 656,050 & 212,142 & 25 & $11,531(-11,501)$ \\
\hline & 13 & Flow & 395 & .4 & Pump 206 & 36 & 868,810 & 360,703 & 29 & $11,541(-11,502)$ \\
\hline & 4 & Pump & 257 & 18.0 & (Abandone & ed in 1957) & 190,000 & $1,460,000$ & 89 & $11,544(-11,506)$ \\
\hline & 14 & Flow & 190 & 1.2 & Pump 45 & 74 & 399,398 & 259,283 & 40 & $11,537(-11,507)$ \\
\hline & 8 & Flow & 527 & .4 & $(\text { Shut in })^{3}$ & & 714,605 & 945,887 & 57 & $11,545(-11,516)$ \\
\hline & 6 & Flow & 225 & Trace & Pump 215 & 48 & $1,390,093$ & 774,923 & 36 & $11,548(-11,517)$ \\
\hline & 10 & Flow & 175 & 1.8 & Pump 51 & 50 & 385,706 & 145,421 & 27 & $11,549(-11,519)$ \\
\hline & 5 & Flow & 518 & .3 & Pump 71 & 77 & 440,571 & 628,257 & 59 & $11,551(-11,520)$ \\
\hline & 9 & Minor & & & (Abandonec & ed in 1948) & 81 & 701 & 90 & $11,564(-11,535)$ \\
\hline Total lease & 1 & Pump & 97 & 81.4 & (Abandonec & ed in 1947) & $\frac{21,463}{5,066,777}$ & $\frac{437,250}{5,224,567}$ & $\frac{95}{51}$ & $11,582(-11,548)$ \\
\hline \multicolumn{11}{|c|}{$\begin{array}{l}\text { Lee Tidewater } \\
\text { Cypress Lumber } \\
\text { Co. "B" (arranged } \\
\text { in order of struc- } \\
\text { tural elev.) }\end{array}$} \\
\hline \multirow[t]{4}{*}{ No. } & 5 & Pump & 109 & None & & (Complete & еec. 18,1962 & & & $11,540(-11,503)$ \\
\hline & 4 & Flow & 437 & 0.3 & Pump 261 & 42 & 906,409 & 155,416 & 15 & $11,548(-11,514)$ \\
\hline & 3 & Flow & 447 & .4 & Pump 20 & 96 & 357,087 & 822,657 & 70 & $11,548(-11,514)$ \\
\hline & 1 & Flow & 137 & 3.7 & Pump & 62 & 577,001 & 403,910 & 41 & $11,556(-11,517)$ \\
\hline Total lease & 2 & Flow & 519 & 1.2 & Pump & 98 & $\frac{275,698}{2,116,196}$ & $\frac{785,132}{2,167,115}$ & $\frac{74}{50}$ & $11,561(-11,521)$ \\
\hline Total field & & & & & & & $7,182,972$ & $7,391,682$ & 51 & \\
\hline
\end{tabular}

2 Fis discovered in September, 1943.

3 Shut in

${ }^{3}$ Shut in on March 12, 1962. 
The highlights and background of the activity connected with drilling in 1962 in the Sunniland field follows:

The Humble Oil and Refining Company, No. 5 Gulf Coast Realties Corporation well, according to permit no. 51 dated November 27, 1962, will be deepened from 11,578 feet to a proposed depth of 11,700 feet. The bottom of the Chamid zone, which is the lower of the two zones containing intervals which have produced in the field, should be reached at a depth of about 11,628 feet.

It is shown in table 1 that in this well the top of the middle member of the Sunniland formation occupies a relatively low structural position as compared with other Sunniland field wells.

This well originally was completed on May 24, 1947, in the open hole from 11,562 to 11,578 feet $(-11,531$ to $-11,547$ feet, subsea). Initial flowing production (table 1) was 518 barrels of $25^{\circ}$ API (American Petroleum Institute) gravity oil, and 0.3 percent BS\&W (basic sediment and water) through a $1 / 4$-inch choke. Accumulated production to October 1, 1962, was 440,571 barrels of oil, with 59 percent (or 628,257 barrels) of the fluid recovery being salt water. During the production test of September 1962 the well pumped 71 BOPD (barrels oil per day) with 77 percent of the fluid recovery being salt water.

The Humble Oil and Refining Company, No. 18 Gulf Coast Realties Corporation well is a new producer which occupies an infield location between four other Gulf Coast Realties Corporation producers separated from the No. 18 well by distances ranging from about one-third to one-half mile. In these surrounding wells production has been obtained for periods of 12 to 15 years.

Recovery on a pumping test of the No. 18 well through 2-inch tubing from a perforated interval in the Sunniland field Chamid zone at 11,585 to 11,589 feet $(-11,551$ to $-11,555$ feet, subsea) was:

178.7 BOPD ( $19.6^{\circ} \mathrm{API}$ corrected gravity)

19.8 barrels BS\&W (158,500 ppm [parts per million]chloride)

Some gas

As shown on table 2 the No. 18 Gulf Coast Realties Corporation well is structurally the highest well in the Sunniland field. Despite this fact, however, the top of the perforations in this well is lower by amounts ranging from 2 to 18 feet than the bottom of the perforated or open-hole interval in any well in the field, with the exception of the No. 1 and No. 4 
Table 2. Structural and Thickness Comparisons of the Producing Intervals in Sunniland Field Wells

\begin{tabular}{l}
\hline \\
Farm and no. \\
\hline Gulf Coast Realties Corporation wells \\
(arranged in order of structural elev. \\
No. 18 \\
11 \\
13 \\
4 \\
14 \\
8 \\
6 \\
10 \\
5 \\
9 \\
1
\end{tabular}

Lee Tidewater Lumber Company " $B$ " wells (arranged in order of structural elev.)
Structural top of Sunniland marker 1$$
\text { (feet) }
$$

$11,527(-11,493)$

$11,531(-11,501)$

$11,541(-11,502)$

$11,544(-11,506)$

$11,537(-11,507)$

$11,545(-11,516)$

$11,548(-11,517)$

$11,549(-11,519)$

$11,551(-11,520)$

$11,564(-11,535)$

$11,582(-11,548)$

$$
\begin{aligned}
& 11,540(-11,503) \\
& 11,548(-11,514) \\
& 11,548(-11,514) \\
& 11,556(-11,517) \\
& 11,561(-11,521)
\end{aligned}
$$

Producing interval

\begin{tabular}{cc}
$\frac{\text { Producing interval }}{\text { Top and bottom }}$ \\
Type completion & $\begin{array}{c}\text { in feet subsea } \\
\text { (thickness) }\end{array}$ \\
\hline
\end{tabular}

Perforated

Open hole

Open hole

Open hole

Open hole

Perforated

Open hole

Open hole

Open hole

Not available

Open hole

$-11,551$ to $-11,555 \quad(4)$
$-11,520$ to $-11,543(23)$
$-11,480$ to $-11,533(53)$
$-11,526$ to $-11,563(37)$
$-11,501$ to $-11,546(45)$
$-11,535$ to $-11,540$ (5)
$-11,525$ to $-11,547(22)$
$-11,536$ to $-11,544$ (8)
$-11,529$ to $-11,547(18)$
$-11,566$ to $-11,592(26)$

Perforated

Open hole

Open hole

Open hole

Open hole

${ }^{1}$ Middle member of the Sunniland formation as defined in Raasch's type section (1954, p. 8). 
Gulf Coast Realties Corporation wells, both of which have been abandoned. When this perforated interval in the No. 18 well is depleted or goes to salt viater, perhaps overlying intervals which have produced in other Sunniland field wells will be opened to production.

This well was drilled to a total depth of 11,806 feet and the bottom of the Chamid zone appears to have been reached at a depth of about 11,604 feet. It is possible that the operator had hoped, in drilling about 202 feet below the bottom of the Chamid zone, to find a third pay interval in the underlying Coskinolinid zone. A promising pumping test of this underlying zone, made through perforations 108 to 130 feet below the bottom of the approximate stratigraphic equivalent of the Chamid reef and in the lower part of Bank's Dade Cyclothem Unit D-2 (1960, p. 1740), was conducted in the Commonwealth, et al., No. 1 M. B. Wisehart and State Board of Education well of the Forty Mile Bend field, shown on figure 1 to be located about 48 miles southeast of the Sunniland field. In this test the zone (11,464 to 11,486 feet) was acidized, and recovery was 20 barrels of $23^{\circ}$ API gravity oil plus considerable salt water.

The Humble Oil and Refining Company, No. 5 Lee Tidewater Cypress Lumber Company " $B$ " well is a new producer which occupies an infield location at a point approximately 0.4 mile equidistant from the four producing wells previously drilled by the Lee Tidewater Cypress Lumber Company. The four producing wells surrounding the new producer have been in production for periods ranging from 14 to 15 years.

Recovery on a 9-hour pumping test of this well from a perforated interval in the Chamid zone from 11,580 to 11,585 feet $(-11,543$ to $-11,548$ feet subsea) was:

\subsection{BOPD (25.3 API gravity) \\ 0.7 percent $\mathrm{BS} \& W$}

It is shown in table 2 that the top of the middle member of the Sunniland formation in this new producer occurs at 11,540 feet $(-11,503$ feet subsea). On this marker the well is not as high as the previously discussed Gulf Coast Realties Corporation No. 18 test, but it is higher than any of the four surrounding Lee Tidewater Cypress Lumber Company producers by amounts ranging from $\&$ to 18 feet. Despite the fuct that these two new producers drilled in 1962 are structurally high, the perforated intervals in both of them are somewhat lower in structural elevation than they are in surrounding producers. When these intervals are depleted or go to salt water, perhaps overlying zones which have produced in the surrounding wells will be opened to production. 


\section{PRODUCTION}

Production figures for the Sunniland field for 1962, as submitted by the Humble Oil and Refining Company operator, are:

\begin{tabular}{lr} 
Month & Barre/s \\
January & 38,584 \\
February & 33,002 \\
March & 36,866 \\
April & 36,082 \\
May & 33,341 \\
June & 32,218 \\
July & 34,042 \\
August & 35,074 \\
September & 34,067 \\
October & 34,972 \\
November & 30,570 \\
December & 35,855 \\
\hline
\end{tabular}

Production was obtained from 11 wells during the months of January through part of July. During the remainder of the year only 10 wells were on production as a result of the shutting in for workover operations of the No. 8 Gulf Coast Realties Corporation well, which had developed a casing leak.

The cumulative total production from the field through December 31, 1962, was 7,247,361 barrels.

\section{PRESSURES}

Table 3 reveals that differential pressures push fluid levels far above the producing intervals in all of the Sunniland field wells. This table also shows that in 1958 the fluid levels, or the depths from which the wells are pumped, varied from about 1,550 to 4,034 feet of depth. As a consequence the oil lifting cost is relatively low.

\section{ENERGY FOR WATER DRIVE}

The original bottom hole shut-in pressure in the Sunniland field, recorded before significant quantities of fluids were withdrawn, was 
Table 3. Sunniland Field Pressures and Fluid Levels

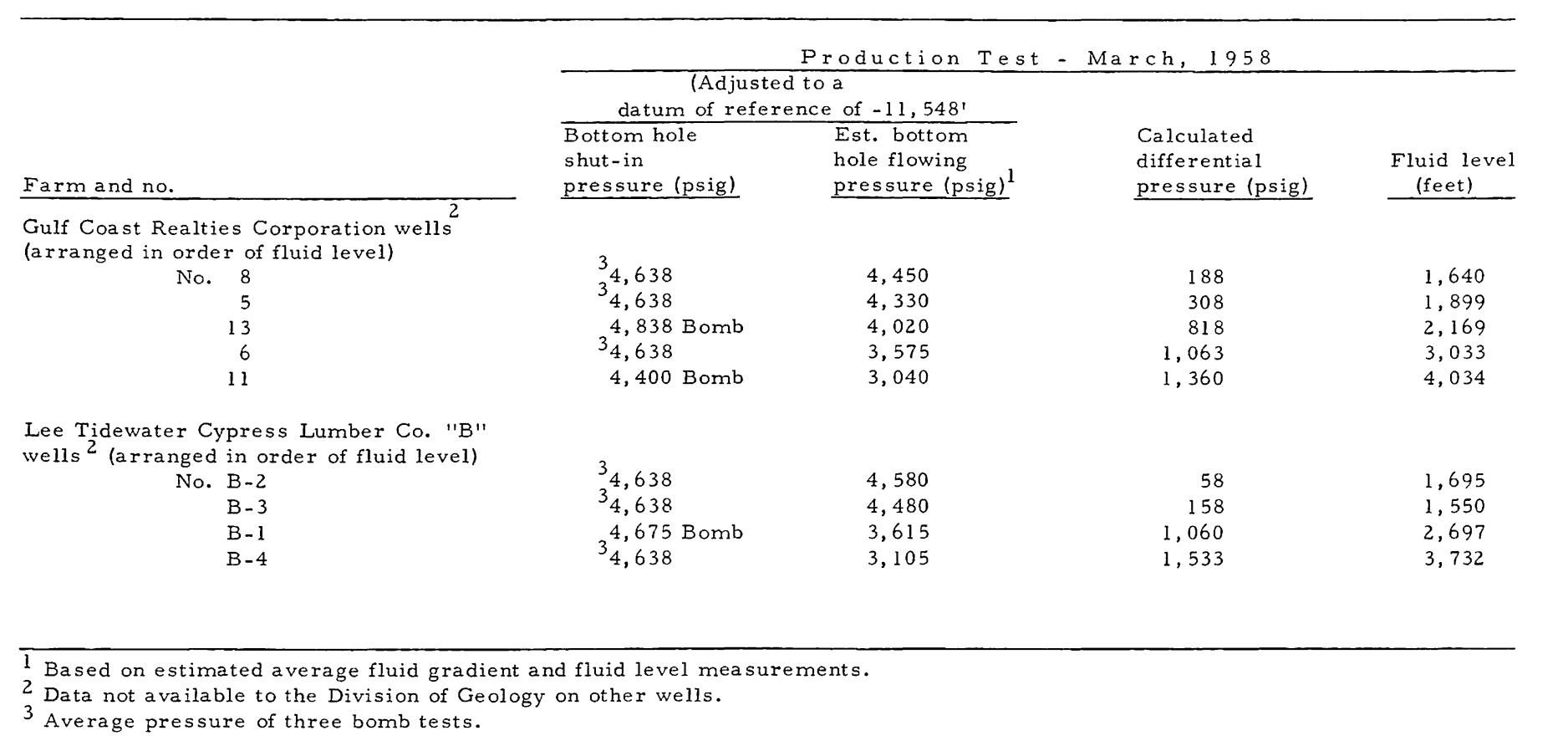


$5,292 \mathrm{psig}$ (pounds per square inch gage). This also is essentially the pressure existing in the Sunniland producing interval at the present time in areas adjacent to the field but far enough removed from it that they are not affected by its production. The difference between this original bottom hole shut-in pressure and the present bottom hole shutin pressure in the field $(4,638 \mathrm{psig})$ is $654 \mathrm{psig}$. This pressure difference, which is equivalent to the pressure exerted by a head of water 1,510 feet high, provides the energy for the active water drive by which the field is produced. The Division of Geology has no information about the artificially induced gradient along which this pressure as discussed above is distributed.

\section{SAL T--WATER ENCROACHMENT}

Levorsen states (1958, p. 452) that the velocity of salt_water encroachment in a water drive pool varies within the range of 100 to 1,000 feet per year. It is hoped that the average rate of encroachment in the Sunniland field is so low that pockets exist in which oil originally in place has not been adversely affected by salt-water incursion.

\section{EXPLORATION}

In 1962 three exploratory wells were completed, and all three have been plugged and abandoned. Data on these wells are given in appendix 1, and the wells are spotted on figure 1, a generalized location map.

During 1962 an amount of 16,378 feet of exploratory footage was drilled in three wells, whereas in 1961, a footage of 87,737 feet was drilled in nine exploratory wells. 1962 follows:

A summary by counties of the highlights of exploratory drilling in

\section{GADSDEN COUNTY}

The Prince and Munroe, No. 1 La Corona well, located about $1 \frac{1}{2}$ miles south-southwest of Quincy, was permitted with a proposed depith of 7,500 feet. However, the well proved to be 95 feet lower, on top of the Lower Tuscaloosa section of Upper Cretaceous Woodbine Age, than 
the Sun Oil Company, No. I American Tobacco Company well, located about 1 mile to the north-northeast. Consequently, the test was abandoned at a total depth of 4,196 feet in Lower Cretaceous sediments after drilling 316 feet below the Lower Tuscaloosa marker.

It was hoped that this well would drill a fault as interpreted from seismic records; however, a fault was not penetrated in the Upper Cretaceous section.

\section{MONROE COUNTY - OFFSHORE}

The California Company, No. 3 State Lease 1011 well, which reached a total depth of 12,850 feet, is shown on figure 3 , a location and information map, to be the sixth offshore well which has been drilled in the Marquesas area. This well is located 790 feet southeast of the same operator's No. 2 State Lease 1011 dry hole and about 7\%/2 miles southwest of the Gulf Oil Corporation, No. 1 State Lease 826-Y well, which produced 15 barrels of oil on a 14 -hour drill stem test from a 59 -foot interval $(12,474-12,533$ feet) in the Sunniland zone. This $826-Y$ well probably could have been developed as a commercial producer if it had been located on land and the oil present at a shallow depth.

\section{SANTA ROSA COUNTY}

The Humble Oil and Refining Company, No. 1 St. Regis Paper Company well was drilled to a total depth of 11,722 feet, terminating in probable Hosston sediments of Lower Cretaceous Coahuilan Age. An important objective of this test of the deeper Lower Cretaceous section was the Rodessa Formation, which Forgotson (1957) defines as the upper member of the lower Glen Rose subgroup of Lower Cretaceous Trinity Age. This formation is productive in the Citronelle field which lies about 50 miles to the west.northwest in Alabama.

In the Lower Tuscaloosa section three conventional cores were taken but none of these contained oil shows. The results of an openhole drill stem test of the top of the Lower Tuscaloosa section $(6,572$ 6,612 feet), run primarily to obtain a sample of formation water for analysis, are:

Recovery (using $1 / 4$-inch top and bottom chokes)

1,000 feet water cushion

4,270 feet salt water $(95,000 \mathrm{ppm}$ chloride) 


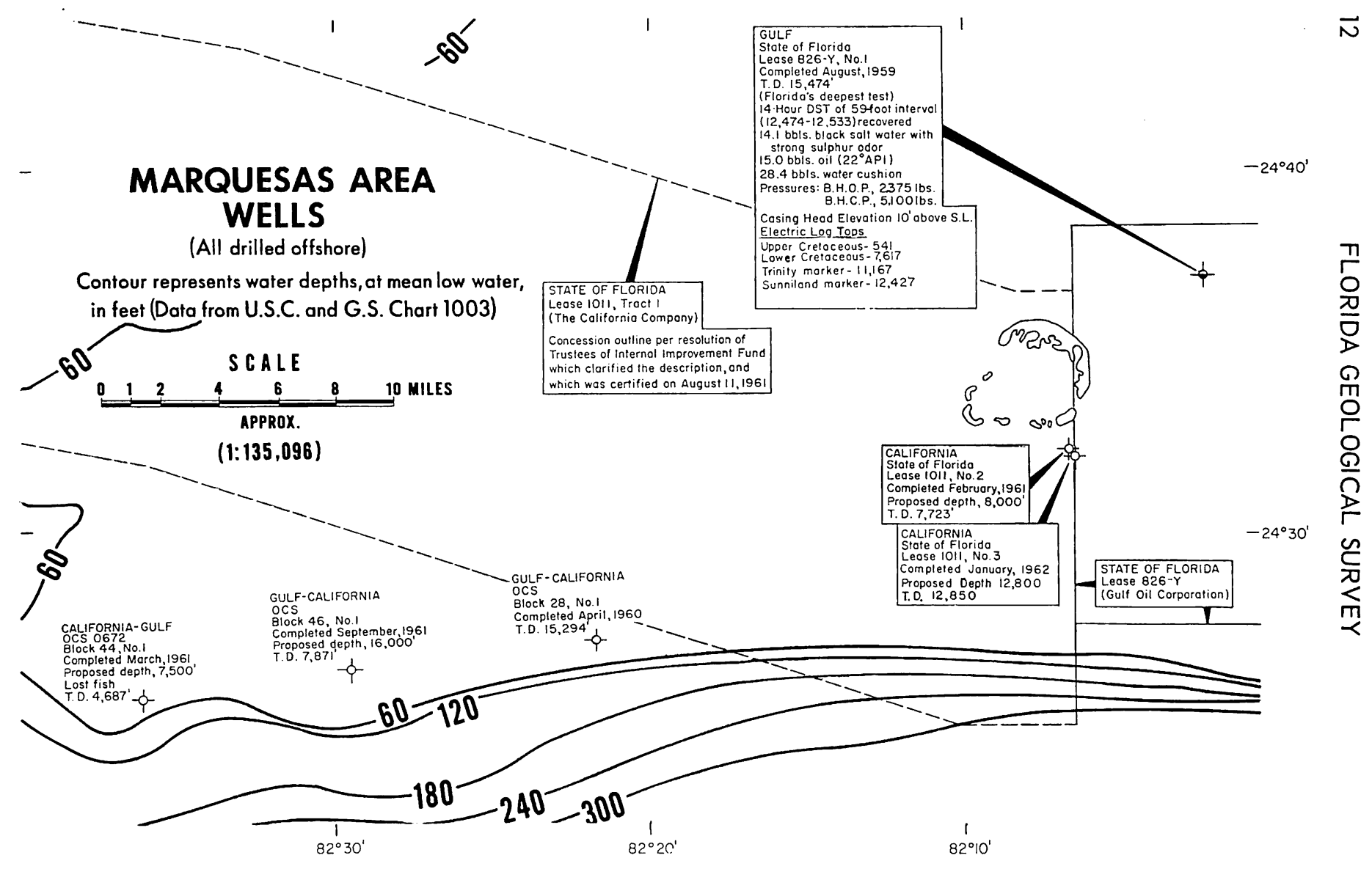

Figure 3. Marquesas area wells. 
Pressures

$$
\begin{aligned}
& \text { BHFP, } 517 \text { to } 2,505 \text { pounds } \\
& \text { SIBHP, 2,905 pounds } \\
& \text { Hydrostatic, } 3,437 \text { pounds }
\end{aligned}
$$

There was recovery from 22 of the 26 sidewall samples taken from 7,638 to 11,387 feet, but no show of oil was reported in any of the samples.

Well control, though very limited at the level of the Rodessa Formation, is adequate to reveal that, on Upper Cretaceous markers, both the Humble and Socony Mobile wells are about normal regionally. This indicates that probably the seismic information used in selecting the locations of both of these wells will need to be reassessed.

\section{LAND}

\section{FLORIDA MAINLAND}

The Division of Geology has specific information on two lease plays in Florida during 1962. First, in the month of July, the Phillips Petroleum Company took a 10-year mineral lease on $36,826.48$ acres in the following parts of Hendry County:

$$
\begin{aligned}
& \text { T. } 43 \text { S., R. } 29 \text { E. } \\
& \text { T. } 43 \text { S., R. } 30 \text { E. } \\
& \text { T. } 43 \text { S., R. } 31 \text { E. } \\
& \text { T. } 44 \text { S., R. } 29 \text { E. } \\
& \text { T. } 44 \text { S., R. } 30 \text { E. } \\
& \text { T. } 44 \text { S., R. } 32 \text { E. }
\end{aligned}
$$

It is reported that Phillips paid a bonus of $\$ 1.00$ per acre plus 50 cents per year rental on this acreage, which lies slightly east of a block leased by the Sinclair Oil and Gas Company.

In a second leasing play, occurring in the latter part of the year, 18,000 acres along the St. Mary's River between Folkston, Charlton County, Georgia, and Hilliard, Nassau County, Florida, were leased by W. B. and E. C. McCarter, Houston, Texas.

The latest information available to the Division of Geology on the total amount of acreage held under oil and gas lease in Florida pertains to 1961, and is from the International Oil and Gas Development Year Book of 1962, p. 55. This source, as supplemented by information from the State Land Office relative to offshore acreage, reveals 
that nine companies in 1961 held oil and gas leases on undeveloped mainland acreage in 54 of Florida's 67 counties, as follows:

\begin{tabular}{l} 
Company \\
\hline Coastal \\
Gulf \\
Humble \\
Mobile \\
Shell \\
Sinclair \\
Sun \\
Texaco \\
Inion
\end{tabular}

Florida mainland acreage under lease in 1961

\begin{tabular}{c}
643,809 \\
76,830 (estimated) \\
152,051 \\
58,922 \\
91,695 \\
92,857 \\
171,024 \\
194,723 \\
14,316 \\
\hline $1,496,227$
\end{tabular}

\section{FLORIDA OFFSHORE}

At the end of 1962, Florida acreage offshore from the west coast of Florida, according to information from the State Land Office, was held by three companies as tabulated below:

\begin{tabular}{l} 
Company \\
\hline California \\
Coastal \\
Gulf
\end{tabular}

Florida offshore acreage under lease at the

$\begin{array}{r}\text { end of } 1962 \\ \hline 734,760 \\ 3,910,460 \\ 979,160 \\ \hline 5,624,380\end{array}$

An additional area of approximately 2,500,000 acres offshore from the west coast of Florida a distance of 3 leagues ( 10.36 miles) were available for lease at the end of 1962. These consist of water bottoms leased under the provisions of State Leases 833 and 826 (Blocks A-J and $\mathrm{O}-\mathrm{U})$. Furthermore, offshore from the Atlantic coastline of Florida, out to a distance of 3 miles, water bottoms are available for oil and gas leasing. However, leasing of any of Florida's offshore acreage which lies within 3 miles of municipalities or bathing beaches is subject to advice of public hearings (Florida Statutes Chapter 253.52). In addition, manmade beaches owned by private parties are not available for oil and gas leasing by the State. 
The lessor, approximate locations, and outlines of State leases located offshore from the west coast of Florida, acreage contained in each lease, and bonuses and annual rentals paid are shown on figure 4. All leases provide that the State's share of production shall be oneeighth of the value of the oil at the wellhead. There also is a 5 percent severance tax on the value of the oil at the wellhead (Florida Statutes Chapter 211.02).

\section{GEOPHYSICS}

Geophysical activity in Florida in 1962 is summarized in table 4.

For 8 weeks in May and June of 1962 the Pan American Petroleum Corporation had a Western Geophysical Compary crew working on federal water mostly off the coast of southern Georgia, with some of the work being off the coast of northern Florida.

During each of the 2 years preceding 1962, the geophysical activity in Florida was:

Crew weeks of

Year geophysical activity

Source

1961

49

International Oil and Gas Development Year Book

1960

89 of 1962, part 1, p. 54 Vernon and Hendry (1960, p. 7)

Crew weeks of geophysical activity in Florida, by counties, of the 21-year interval, 1941-61, inclusive, were obtained from the International Oil and Gas Year Book pertaining to each of the included years, and are shown in table 5 .

In 1959 there was an additional 17 crew weeks of seismic activity over water bottom acreage which lies beyond the jurisdiction of the State of Florida (further offshore than 3 leagues or 10.36 statute miles). 


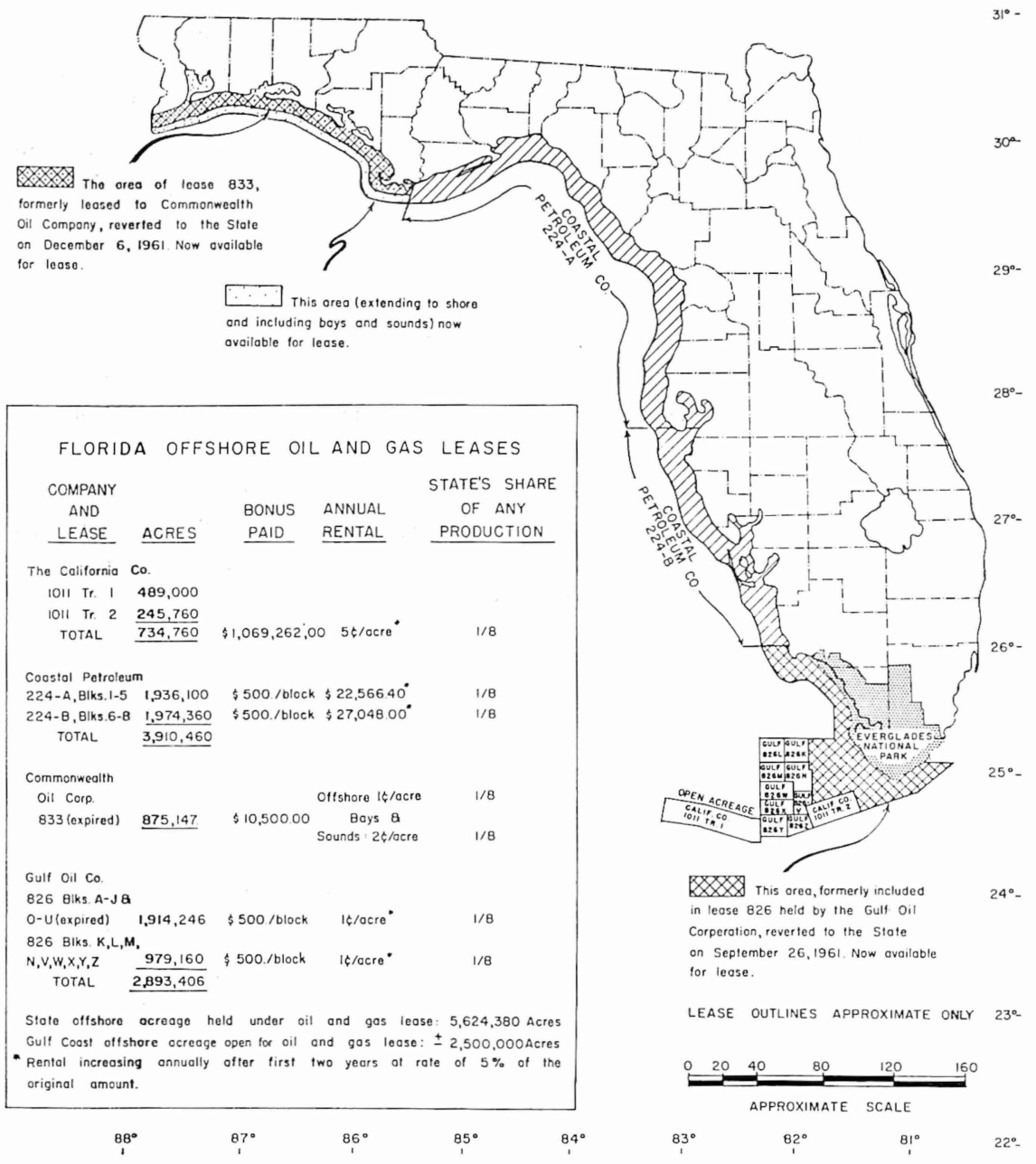

Figure 4. Offshore Florida state leases, December 31, 1962 
Table 4. Geophysical Activity in Florida in 1962

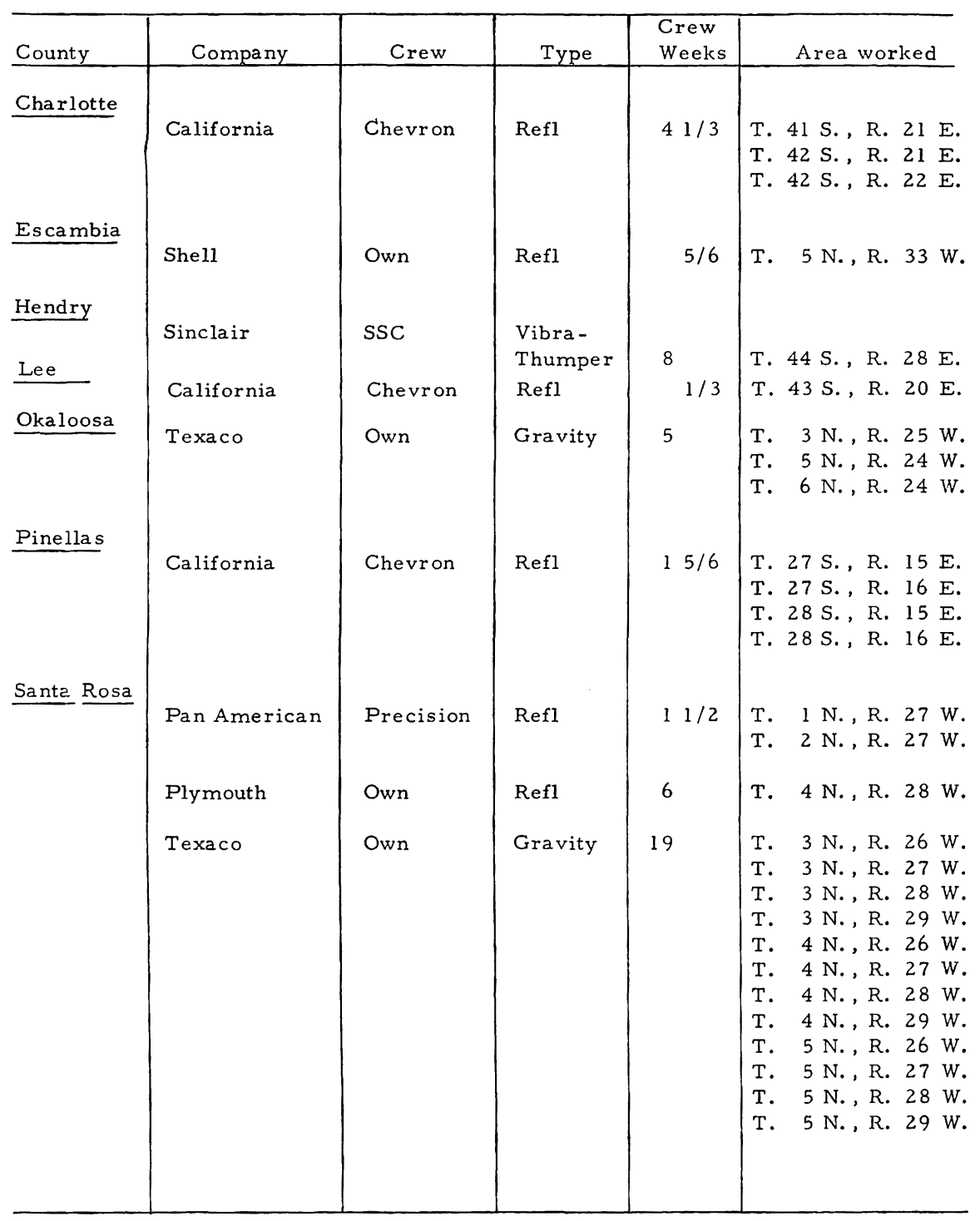


Table 5. Crew Weeks of Geophysical Activity in Florida 1941 to 1961 , Inclusive

\begin{tabular}{|c|c|c|c|c|c|c|c|}
\hline County & Gravity & Mag. & $\begin{array}{l}\text { Air } \\
\text { mag. }\end{array}$ & Resist. & $\begin{array}{l}\text { Core } \\
\text { drill }\end{array}$ & Seismic & Total \\
\hline Ala chua & 42 & 14 & 0.33 & & & 7 & 63.33 \\
\hline Baker & 26.66 & 16.3 .3 & .33 & & & & 43.32 \\
\hline Bay & 60.25 & 15 & 1.33 & & 11 & 18 & 105.58 \\
\hline Bradford & 12.33 & 3 & .33 & & & & 15.66 \\
\hline Brevard & 13.66 & 4.75 & & & & 14 & 32.41 \\
\hline Broward & 6 & .5 & & & 2 & 2 & 10.50 \\
\hline Calhoun & 67 & 3 & .33 & & 17 & 14 & 101.33 \\
\hline Charlotte & 25 & 3.5 & & 1 & 13 & 70 & 112.50 \\
\hline Citrus & 28 & 10 & & & .5 & & 38.50 \\
\hline Clay & 13.33 & 13.33 & & & & 3.5 & 30.16 \\
\hline Collier & 33.5 & 7.5 & & 4 & 318.5 & 158 & 521.50 \\
\hline Columbia & 41.5 & 5 & & & 3 & 7.16 & 56.66 \\
\hline Dade & 21 & 4.25 & & & & 53 & 78.25 \\
\hline DeSoto & 31 & 1.5 & & & 17 & 60 & 109.50 \\
\hline Dixie & 31.5 & 19.5 & & & 71 & 12 & 134.00 \\
\hline Duval & 17.5 & 17.66 & & & & 3.25 & 38.41 \\
\hline Escambia & 64 & 11 & 3 & & 95 & 64 & 237.00 \\
\hline Flagler & 28 & 4 & & & & 2 & 34.00 \\
\hline Franklin & 26.33 & & .33 & & 12 & 31 & 69.66 \\
\hline Gadsden & 37.5 & 17 & .33 & & 27 & 21 & 102.83 \\
\hline Gilchrist & 26.5 & 4.5 & .33 & & & & 31.33 \\
\hline Glades & 25 & 2.5 & & & 16 & 27 & 70.50 \\
\hline Gulf & 60.75 & 8 & .33 & & 12 & 61 & 142.08 \\
\hline Ha milton & 20.83 & 4 & .33 & & 18 & & 43.16 \\
\hline Hardee & 42.5 & 3 & & & 35.5 & 19 & 100.00 \\
\hline Hendry & 21 & $1 . .5$ & & & 63 & 87 & 172.50 \\
\hline Hernando & 33.5 & 13.25 & & & 46.5 & & 93.25 \\
\hline Highlands & 38.5 & 6.25 & & & 16 & 56 & 116.75 \\
\hline Hillsborough & 59 & 2 & & & 16 & 21 & 98.00 \\
\hline Indian River & 9 & 2.33 & & & & 29 & 40.33 \\
\hline Holmes & 67.83 & 29 & 1 & & & 47 & 144.83 \\
\hline Jackson & 73.33 & 27 & .33 & & 52 & 31 & 183.66 \\
\hline Jefferson & 38.33 & 15 & .33 & & & & 53.66 \\
\hline Lafayette & 35.5 & 6.5 & .33 & & 43 & 12 & 97.33 \\
\hline Lake & 34.33 & 9.25 & & & & 6 & 49.58 \\
\hline Lee & 11 & 3.5 & & 2 & 27 & 54 & 97.50 \\
\hline Leon & 45 & 13.75 & .33 & & 6 & & 65.08 \\
\hline Levy & 45 & 22.91 & .33 & & 14.5 & & 82.74 \\
\hline Liberty & 30.33 & 10 & .33 & & 6 & 16 & 62.66 \\
\hline Madison & 49 & 10 & .33 & & 6 & 3 & 68.33 \\
\hline Manatee & 23 & 9 & & & & 40 & 72.00 \\
\hline Marion & 36 & 28.25 & & & & 2 & 66.25 \\
\hline Martin & 4 & 1.33 & & & 3 & 10 & 18.33 \\
\hline Monroe & 69.5 & 17.25 & & & & 116 & 202.75 \\
\hline Nassau & 15.5 & 13.66 & & & & 4 & 33.16 \\
\hline Okaloosa & 77.3 & 14 & 5 & & 26 & 22 & 144.30 \\
\hline Okeechobee & 25 & 6.25 & & & 30 & 60 & 121.25 \\
\hline Orange & 17.83 & 8.75 & & & 23 & 1 & 50.58 \\
\hline Osceola & 23.5 & 7.33 & & & 28.5 & 45 & 104.33 \\
\hline Palm Beach & 41 & 10 & & & 20 & 45 & 116.00 \\
\hline Pasco & 58 & 4 & & & 60 & & 122.00 \\
\hline Pinellas & 18.5 & 1 & & & & & 19.50 \\
\hline
\end{tabular}


Table 5. (Continued)

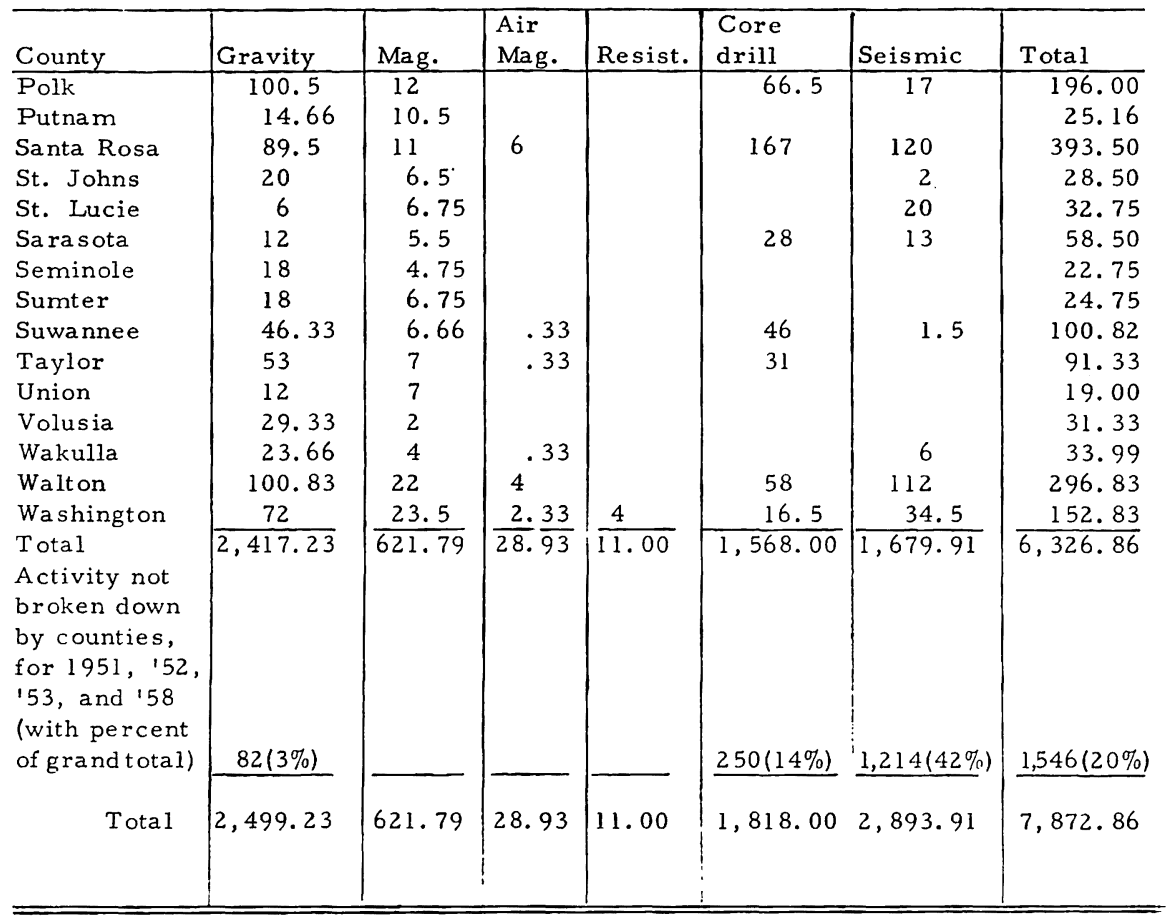





\section{BIBLIOGRAPHY}

Banks, J. E

1960 Petroleum in Commanche (Cretaceous) section, Bend Area, Florida: Am. Assoc. Petroleum Geologists Bull., v. 44, no. 11, p. 1737-1748, 5 fig., 4 tables.

Forgotson, J. M. , Jr.

1957 Stratigraphy of Comanchean Cretaceous Trinity group: Am. Assoc. Petroleum Geologists, v. 41 , p. 2328.

Frascogna, X. M. (editor)

1957 Mesozoic - Paleozoic producing areas of Mississippi and Alabama: Mississippi Geological Society, v. 1.

International Oil Scouts Association

1962 International oil and gas development yearbook of 1962 (review of 1961), pt. 1, v. 32, p. $54-57$.

Levorsen, A. I.

1958 Geology of petroleum: W. H. Freeman and Company, San Francisco, California.

Raasch, Albert C., Jr.

1954 The Sunniland oil field of Collier County, Florida. Unpublished Master Thesis, Florida State University, p. 1-33. Florida State University Strozier Library file no. $553.28 \mathrm{R} 111 \mathrm{~s}$.

1955 Sunniland oil field of Collier County, Florida (abst.): Meeting Program of Eastern Section, Geol. Soc. America Bull., p. 17.

Vernon, Robert 0.

1961 (and Hendry, Charles W., Jr.) Exploration for oil and gas in Florida: Florida Geol. Survey, 1960 Supplement to Inf. Circ. 1 (revised), 16 p., 1 fig., 4 tables, 1 photograph. 

INFORMATION CIRCULAR NO. 42

APPENDIX

EXPLORATORY WELL INFORMATION, 1962 
Sunniland Field

\begin{tabular}{|c|c|c|c|c|c|}
\hline $\begin{array}{c}\text { Permit } \\
\text { no. }\end{array}$ & FGS no. & Company or owner & Well name & Location & Well data \\
\hline 51 & $W-1495$ & $\begin{array}{l}\text { Humble Oil and } \\
\text { Refining Co. }\end{array}$ & $\begin{array}{l}\text { No. } 5 \text { Gulf Coast } \\
\text { Realties Corporation }\end{array}$ & $\begin{array}{l}600^{\prime} \mathrm{E} \text { of } W / L \text { and } \\
660^{\prime} \mathrm{N} \text { of S/L, sec. } 20, \\
\text { T. } 48 \text { S. , R. } 30 \mathrm{E} \text {. }\end{array}$ & $\begin{array}{l}\text { Elev. - 31' DF } \\
\text { Comp. - November } 27,1962 \\
\text { TD - 11,621.79 feet }\end{array}$ \\
\hline
\end{tabular}

REMARKS: (1) Well to be deepened; proposed new depth 11,700 feet.

(2) This well originally was completed May 24, 1947, in the Sunniland producing $z$ one at a total depth of 11,578 feet. This was an open-hole completion from 11,562 to 11,578 feet. Initial flowing production was 518 barrels of $25^{\circ}$ API gravity oil through $\frac{1}{4}$-inch choke.

Accumulated production to October 1, 1962, was 440,571 barrels of oil, with 59 percent (or 628,257 barrels) of the fluid recovery being salt water.

During production test of September 1962, the well pumped 71 BOPD.

An amount of 77 percent of fluid recovery was salt water.

(3) This well occupies a relatively low position on top of the Sunniland marker $(-11,520$ feet $)$ 


\section{COLLIER COUNTY}

Sunniland Field

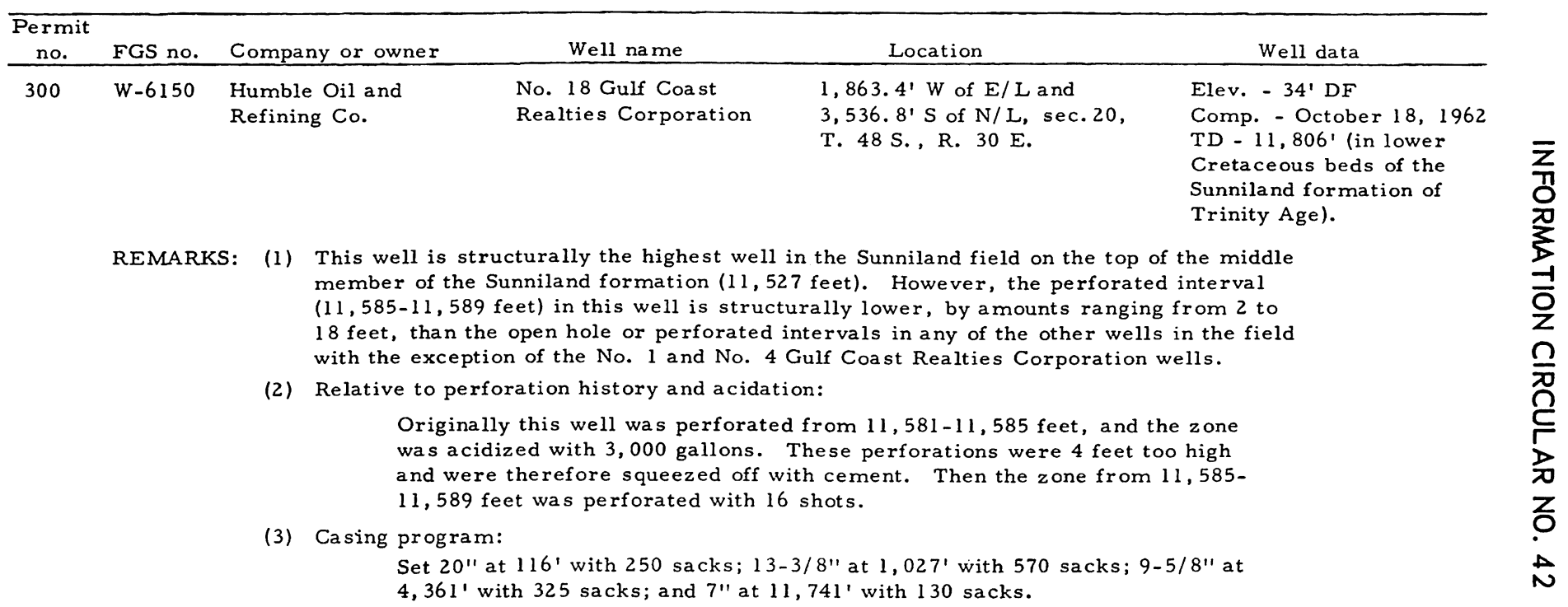

(4) Production test:

Pump from perforations $(11,585-11,589$ feet) through 2 " tubing:

178.7 BOPD $\left(19.6^{\circ}\right.$ corrected gravity)

$+19.8 \mathrm{BS} \& W(158,500$ ppm chloride)

+ Some gas

GOR was 100 to

Tubing pressure was 120 pounds 
Sunniland Field

\begin{tabular}{|c|c|c|c|c|c|}
\hline $\begin{array}{c}\text { Permit } \\
\text { no. }\end{array}$ & EGS no. & Company or owner & Well name & Location & Well data \\
\hline 300 & W- & $\begin{array}{l}\text { Humble Oil and } \\
\text { Refining Company }\end{array}$ & $\begin{array}{l}\text { No. } 5 \text { Lee Tidewater } \\
\text { Lumber Co. "B" }\end{array}$ & $\begin{array}{l}\text { 1, } 926.6^{\prime} \mathrm{N} \text { of } \mathrm{S} / \mathrm{L} \text { and } \\
\text { 1,831.1' W of } \mathrm{E} / \mathrm{L} \text {, sec. } 13 \text {, } \\
\text { T. } 48 \text { S., R. } 29 \mathrm{E} \text {. }\end{array}$ & $\begin{array}{l}\text { Elev. }-37^{\prime} \mathrm{DF} \\
\text { Comp. - December } 18,1962 \\
\text { TD - 11,651' }\end{array}$ \\
\hline
\end{tabular}

REMARKS: (1) Proposed depth: 11,850 feet.

(2) No sidewall cores taken.

(3) Recovery on a 9-hour pumping test from a perforated interval in the Chamid zone from 11,580 to 11,585 feet was:

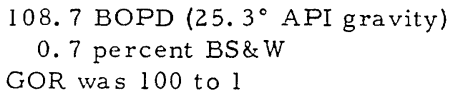


GADSDEN COUNTY

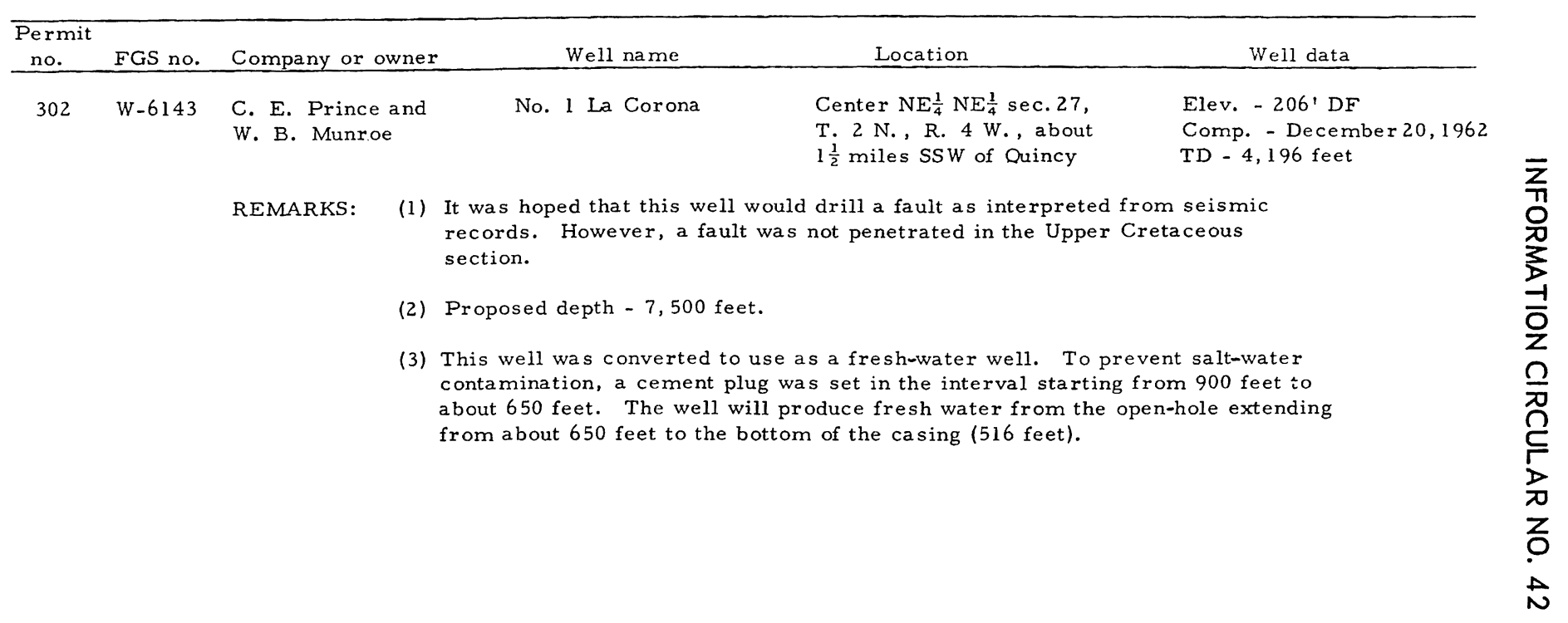




\begin{tabular}{|c|c|c|c|c|c|}
\hline $\begin{array}{l}\text { Permit } \\
\text { no. }\end{array}$ & FGS no. & Company or owner & Well name & Location & Well data \\
\hline 298 & $W-5970$ & The California Co. & No. 3 State Lease 1011 & $\begin{array}{l}\text { Lat. } 24^{\circ} 32^{\prime} 05^{\prime \prime} \mathrm{N} \text {. } \\
\text { Long. } 82^{\circ} 06^{\prime} 35^{\prime \prime} \mathrm{W} \text {. } \\
-15 \mathrm{mi} \text {. SW of Key West, } \\
8 \mathrm{mi} \text {. SE of Marquesas Keys. } \\
\text { Located } 790^{\prime} \mathrm{SE} \text { of same } \\
\text { operator's No. } 2 \text { State } \\
\text { Lease } 101 \mathrm{l}\end{array}$ & $\begin{array}{l}\text { Elev. - } 57^{\prime} \text { DF } \\
\text { Comp. - January 13, } 1962 \\
\text { TD - 12, 850' (probably } \\
\text { Lower Cretaceous) }\end{array}$ \\
\hline
\end{tabular}

REMARKS:

(1) This was a seismic location.

(2) Proposed depth, 12,800 feet. Planned as a Lower Cretaceous test.

(3) Casing program:

26 -inch casing set at 116 feet

20 -inch casing set at 636 feet with 620 sacks

9 5/8-inch casing set at 5,654 feet with 500 sacks

(4) According to Dixie Geological Service (Nov. 15, 1962), the following cores were taken:

$$
\begin{aligned}
& \text { Core 12, 325'-12,368' Rec. 34' No details } \\
& \text { Core 12,368'-12,393' Rec. 32' No details }
\end{aligned}
$$

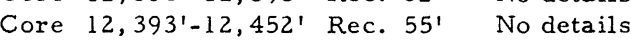

$$
\begin{aligned}
& \text { Core 12,452'-12,473' Rec. 20.1' No details } \\
& \text { Core 12,473'-12,561' Rec. 73' No details } \\
& \text { Core 12,561'-12,600' Rec. 34' No details }
\end{aligned}
$$




\section{SANTA ROSA COUNTY}

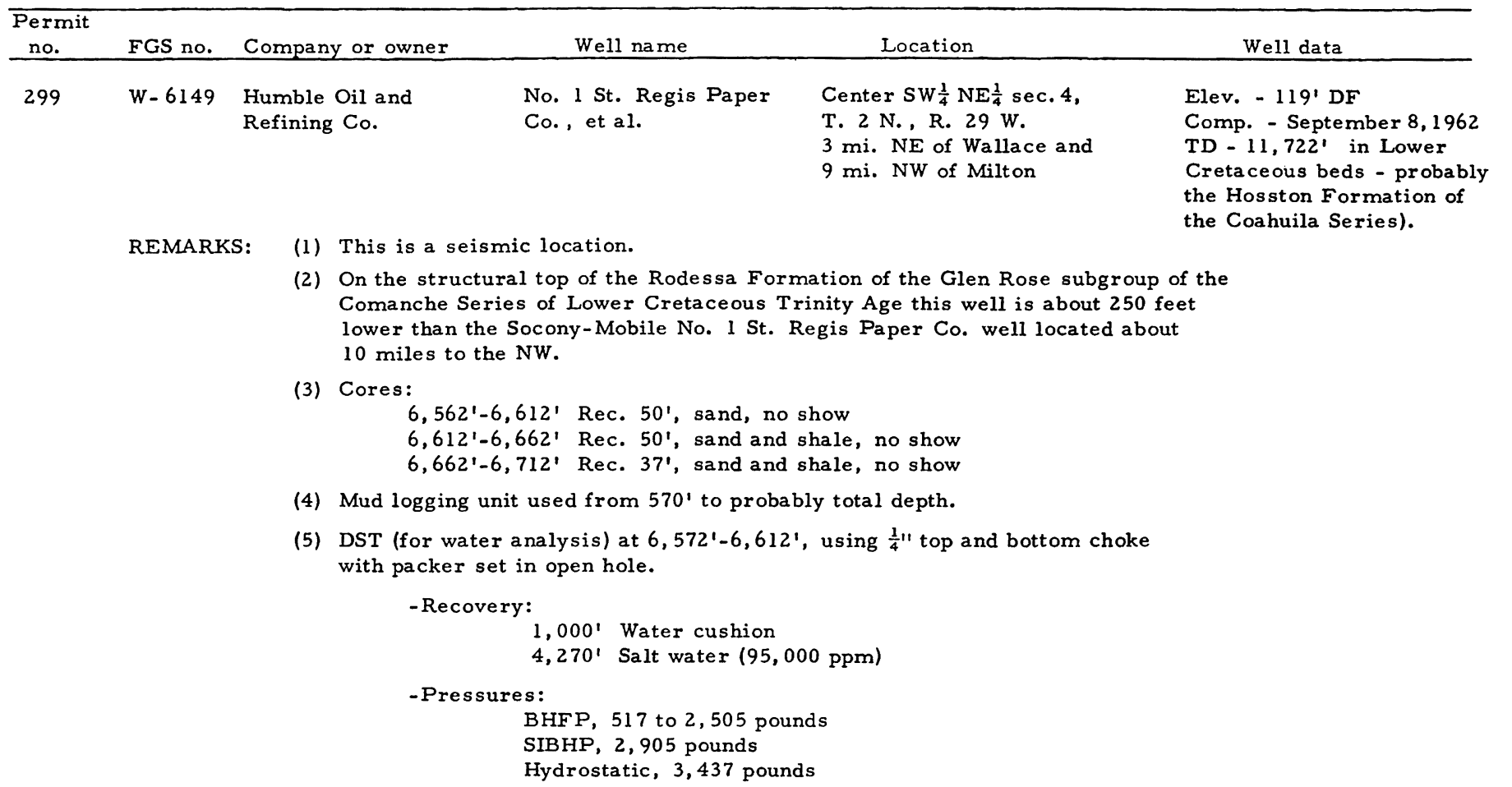

(6) There was recovery from 22 of the 26 sidewall samples taken from 7,632 to 11, 387 feet. All no show. 




